\title{
Are Reptiles Reservoirs of Leptospirosis? A Brief Discussion Based on Serological Studies
}

\author{
Felipe Fornazari \\ Departamento de Higiene Veterinária e Saúde Pública, Faculdade de Medicina Veterinária e Zootecnia, São Paulo State University (UNESP), Prof. Dr. \\ Walter Maurício Correa Street, Botucatu, São Paulo State 18618-681, Brazil
}

Recently, a paper in EcoHealth by Pérez-Flores et al. (2017) on the risk of human leptospirosis from Mexican crocodiles caught my attention because it involves an interesting and poorly studied subject: the role of reptiles as reservoirs of leptospirosis and their risks for public health. My goal here is not to disagree with the authors' statements, but to contribute to the discussion on this topic and consider other publications that have presented similar results. This brief contribution focuses mainly on the importance of the Microscopic Agglutination Test (MAT) to predict the reservoir status of reptiles.

A great number of mammal species can harbor leptospires in their tissues. For a long time researchers have wondered whether reptiles can also carry leptospires, and some studies conducted decades ago have shown evidence of this hypothesis (Glosser et al. 1975). Surprisingly, little research on this subject was performed since then. The few studies in the literature are usually limited to low sample size and serological tests. Thus, leptospirosis in reptiles still remains an unexplored field, besides the great relevance of the disease and the high biodiversity of this animal group.

MAT is the the standard serological test for leptospirosis and has been the most employed in studies with reptiles, but what conclusions may we draw from this test? A common mistake I have often observed in the literature is that MAT positivity "suggests that reptiles may play a role

Published online: May 12, 2017

Correspondence to: Felipe Fornazari, e-mail: ff_vet@yahoo.com.br as reservoir of leptospirosis". In my opinion, such conclusion is usually precipitated. MAT indicates the presence of antibodies against leptospires, thus, it suggests the level of exposure against this pathogen-without necessarily the development of chronic infection, which is a necessary condition that defines a reservoir of leptospirosis. My statement is based on the scientific literature, which indicates the poor value of MAT as a predictor of chronic infection (Harkin et al. 2003; Lilenbaum et al. 2009; Ellis 2015). This fact is justified by several intrinsic limitations of MAT, the characteristics of etiological agent and the immune response of infected animals. These aspects have been widely discussed and I recommend the cited literature for detailed information (Levett 2001; Ellis 2015). I will focus here on why seropositive animals are usually not reservoirs of leptospirosis.

Consider the following conditions in Leptospira infection: low pathogenicity of the infecting strain; low infectious dose; and low specificity between the infected animal species and the Leptospira strain. Such conditions exemplify how animals will not necessarily develop chronic infection but may have anti-Leptospira antibodies-and a positive result in MAT. In the two first cases, a common outcome is the rapid suppression of leptospires by the immune system, without further development of infection. In the third example, an acute infection may progress, characterized by bacteremia, dissemination of leptospires in various tissues and manifestation of disease symptoms. However, the maintenance of bacteria in renal tissue will probably not 
occur and, consequently, the infected animal cannot be considered a reservoir. This failure to establish a chronic infection is particularly common when leptospires are not adapted to a given host. Still, this latter case usually results in a stronger immune response compared to the other two, with higher and lasting antibodies titers.

Therefore, we should consider that several-and unknown-factors influence the dynamics of Leptospira infection, although only a few examples have been presented here. It is extremely difficult to establish an association between MAT and infection status due to many variables related to bacterial diversity, laboratorial tests and animal species. For instance, high antibody titers in MAT can indicate chronic infection, but the contrary is also true, and animals without evidence of leptospires in kidneys commonly exhibits high antibody levels (Harkin et al. 2003; Fornazari et al. 2012; Vieira et al. 2016). One of the few consensuses in the literature is that titers equal to or higher than 800 in MAT indicates recent infection. But even this criterion is constantly under discussion and is considered invalid by many researchers. One exception that may contradict my standpoint occurs when high prevalences are obtained for a single serovar. In this case, the reservoir status is more likely. A classic example is the high positivity of Norway rats (Rattus norvegicus) for Icterohaemorrhagiae serovar.

In view of the broad utilization of serological tests on reptiles and the lack of data regarding the pathophysiology of leptospirosis in these animals, I emphasize the need for a careful interpretation of MAT to avoid hasty conclusions. In addition to consistent epidemiological or molecular analysis, we could make deeper inferences on the MAT results. But in the absence of such studies, I consider the reservoir status of reptiles doubtful based only in serological tests.

I truly believe that reptiles can be natural reservoirs of certain Leptospira strains, given the (1) cosmopolitan nature of this bacterium, (2) the close contact of some animals with aquatic biomes, such as crocodilians and chelonians, (3) and the evidence of leptospires in reptiles using direct tests of diagnosis, particularly the polymerase chain reaction (PCR). But, as far as I know, there is still no strong evidence of any reptile species as an important reservoir of leptospirosis, given that the few publications using PCR reported low prevalences (Biscola et al. 2011; Alves Júnior 2013; Jobbins and Alexander 2015). A recent study in Brazil presented interesting results on this topic, in which a considerable positivity $(16.6 \% ; 11 / 66)$ was found in Geoffroy's side-necked turtles (Phrynops geoffroanus) using PCR in cloacal and gastric content (Oliveira et al. 2016). Similar research including large sample sizes and direct methods of diagnosis is urgently needed to complement current and future serological studies.

\section{RefERENCES}

Alves Júnior JRF (2013) Leptospira spp. e Brucella spp. em tartarugas-da-Amazônia (Podocnemis expansa) do vale do rio Araguaia-GO. Ph.D. Thesis. Universidade Estadual Paulista, Brasil.

Biscola NP, Fornazari F, Saad E, Richini-Pereira VB, Campagner MV, Langoni H, Barraviera B, Ferreira Junior RS (2011) Serological investigation and PCR in detection of pathogenic leptospires in snakes. Pesquisa Veterinária Brasileira 31:806-811

Ellis WA (2015) Animal leptospirosis. In: Leptospira and Leptospirosis, Adler B (editor), Heidelberg, Germany: Springer, pp 99-137

Fornazari F, Silva RC, Richini-Pereira VB, Beserra HE, Luvizotto MC, Langoni H (2012) Comparison of conventional PCR, quantitative PCR, bacteriological culture and the Warthin Starry technique to detect Leptospira spp. in kidney and liver samples from naturally infected sheep from Brazil. Journal of Microbiological Methods 90:321-326

Glosser JW, Sulzer CR, Eberhardt M, Winkler WG (1975) Cultural and serological evidence of Leptospira interrogans serotype Tarassovi infection in turtles. Journal of Wildlife Diseases 10:429-435

Harkin KR, Roshto YM, Sullivan JT, Purvis TJ, Chengappa MM (2003) Comparison of polymerase chain reaction assay, bacteriologic culture, and serologic testing in assessment of prevalence of urinary shedding of leptospires in dogs. Journal of the American Veterinary Medical Association 222:1230-1233

Jobbins SE, Alexander KA (2015) Evidence of Leptospira sp. infection among a diversity of African wildlife species: beyond the usual suspects. Transactions of the Royal Society of Tropical Medicine and Hygiene 109:349-351

Levett PN (2001) Leptospirosis. Clinical Microbiology Reviews $14: 296-326$

Lilenbaum W, Varges R, Ristow P, Cortez A, Souza SO, Richtzenhain LJ, Vasconcellos SA (2009) Identification of Leptospira spp. carriers among seroreactive goats and sheep by polymerase chain reaction. Research in Veterinary Science 87:1619

Oliveira JP, Kawanami AE, Silva AS, Chung DG, Werther K (2016) Detection of Leptospira spp. in wild Phrynops geoffroanus (Geoffroy's side necked turtle) in urban environment. Acta Tropica 164:165-168

Pérez-Flores J, Charruau P, Cedeño-Vázquez R (2017) Evidence for wild crocodiles as a risk for human leptospirosis, Mexico. EcoHealth 14:58-68

Vieira AS, Narduche L, Martins G, Péres IAHFS, Zimmermann NP, Juliano RS, Pellegrin AO, Lilenbaum W (2016) Detection of wild animals as carriers of Leptospira by PCR in the Pantanal biome, Brazil. Acta Tropica 163:87-89 